\title{
Star quality and competitive balance? Television audience demand for English Premier League football reconsidered
}

\author{
N. Scelles
}

Faculty of Health Sciences and Sport, University of Stirling, UK-FK9 4LA Stirling, UK

Faculty of Health Sciences and Sport

University of Stirling

Pathfoot Building

Stirling

FK9 4LA

UK

E-mail: nicolas.scelles@ @stir.ac.uk

Accepted for publication in Applied Economics Letters published by Taylor and Francis

\section{Star quality and competitive balance? TV audience in English football}

The aim of this article is to investigate the determinants of television audience for English Premier League (EPL) football matches during the 2013-2014 season $(n=154)$. The model is adapted from Buraimo and Simmons (2015) who concluded that star quality was an important determinant of television audiences for the EPL over the 2000-2008 period, whereas uncertainty of outcome and championship, Europe and relegation contention were not. Their measures for contention are replaced by indicators based on Scelles et al.'s (2013b 2016) competitive intensity. Results show a significant positive impact of star quality but also championship and Champions League intensity and no significant impact of Europa League, potential Europa League and relegation intensity. Based on these results, the article suggests that the EPL should encourage both star quality and competitive balance so that all teams can be competitive in terms of the title or qualification for the UEFA Champions League. Given the differences in revenue generation between English teams, the best way to achieve both star quality and competitive balance would be through the introduction of a European Super League. However, this conclusion based on television audience contradicts that of Scelles et al. (2016) based on stadium attendance.

\section{Acknowledgements}

I am grateful to Babatunde Buraimo, Stephen Morrow and an anonymous referee for their very helpful comments. Errors are my own.

\section{Disclosure statement}

No potential conflict of interest is reported by the author. 


\title{
Star quality and competitive balance? Television audience demand for English Premier League football reconsidered
}

\author{
The aim of this article is to investigate the determinants of television audience for \\ English Premier League (EPL) football matches during the 2013-2014 season ( $n=$ \\ 154). The model is adapted from Buraimo and Simmons (2015) who concluded that \\ star quality was an important determinant of television audiences for the EPL over the \\ 2000-2008 period, whereas uncertainty of outcome and championship, Europe and \\ relegation contention were not. Their measures for contention are replaced by \\ indicators based on Scelles et al.'s (2013b 2016) competitive intensity. Results show a \\ significant positive impact of star quality but also championship and Champions \\ League intensity and no significant impact of Europa League, potential Europa League \\ and relegation intensity. Based on these results, the article suggests that the EPL should \\ encourage both star quality and competitive balance so that all teams can be \\ competitive in terms of the title or qualification for the UEFA Champions League. \\ Given the differences in revenue generation between English teams, the best way to \\ achieve both star quality and competitive balance would be through the introduction of \\ a European Super League. However, this conclusion based on television audience \\ contradicts that of Scelles et al. (2016) based on stadium attendance.
}

Keywords: star quality; competitive balance; competitive intensity; television audience; English Premier League football

JEL classification: L82; L83

\section{Introduction}

The sports economics literature includes numerous articles focusing on determinants of stadium attendance in professional football leagues (e.g. Allan 2004; Andreff and Scelles 2015; Pawlowski and Anders 2012; Scelles et al. 2013a 2013b 2016). However, the determinants of TV audience have been less commonly investigated in football although some recent articles have tried to fill the gap (Buraimo and Simmons 2015; Cox 2015; Wang, Goossens, and Vandebroek 2016). These recent attempts can be explained by the dramatic increase in TV rights for the main European football leagues since the 1980s, particularly for 
the English Premier League (EPL). For the 2016-2019 period, the EPL generates a record of more than $£ 8.3$ bn (Rumsby 2016).

In their article on the determinants of TV audience in the EPL over the 2000-2008 period, Buraimo and Simmons (2015) suggest that the notion of a pure sporting contest in which uncertainty of outcome matters is no longer relevant, arguing that what is more important now is the extent to which sports teams and leagues can increase the quality of the talent on show. They also include in their model three dummies for champion, European qualification and relegation contention equal to 1 if either of the teams in the match can respectively win the championship, qualify for either the Champions League or the Europa League (but not win the championship), or avoid relegation if it was to win all its remaining games while others only take an average of one point from their remaining games $(0$ otherwise). The authors find no significant impact for these three dummies.

In this article, it is suggested that Buraimo and Simmons' (2015) measures for contention can be improved. They consider that a team is in contention to win the championship even where a gap of 20 points exists to the first-ranked team as long as at least 10 games remain. However, it is questionable that such a team is really still in contention to win the championship or perceived as such by fans. Based on attendance in the French football Ligue 1, Scelles et al. (2013b) find that fans are more sensitive to a possibility of change (competitive intensity) at the end of the next two or three games rather than beyond that, while Scelles et al. (2016)'s findings suggest that from the fans' perspective, the importance of the different prizes matters more than the temporal horizon required to reach a prize (meaning that if one team needs one game to reach a ranking qualifying for the Champions League and two or three games to reach first position, the latter matters more for fans). Moreover, it seems more appropriate to consider competitive intensity only during the second half of a season, when more is at stake. Hence, the model proposed by Buraimo and 
Simmons (2015) is applied but their measures for contention are replaced with indicators based on Scelles et al. (2013b 2016).

\section{Model}

The logarithm of audience for the $n=154$ games broadcasted in the EPL in the 2013-2014 season serves as the dependent variable in the model (AUD). Based on Buraimo and Simmons (2015), the function estimated is of the form:

$\ln (A U D)=\mathrm{b}_{0}+\mathrm{b}_{1}$ WAGE $+\mathrm{b}_{2}$ POINTS $+\mathrm{b}_{3}$ OTHER MATCHES $+\mathrm{b}_{4} D E R B Y+\mathrm{b}_{5}$ WEEKDAY + $\mathrm{b}_{6} B O X I N G D A Y+\mathrm{b}_{7} B T$ SPORT $+\mathrm{b}_{8}$ OUTCOME UNCERTAINTY + $\mathrm{b}_{9}$ CHAMPIONSHIP INTENSITY $+\mathrm{b}_{10}$ CHAMPIONS LEAGUE INTENSITY + $\mathrm{b}_{11}$ EUROPA LEAGUE INTENSITY $+\mathrm{b}_{12}$ POTENTIAL EUROPA LEAGUE INTENSITY + $\mathrm{b}_{13}$ RELEGATION INTENSITY

where WAGE is the sum of the two teams' relative wages as a proxy for star quality, POINTS the sum of the two teams' points per game prior to the match, OTHER MATCHES a dummy equal to 1 if there were other matches being broadcast at the same time and 0 otherwise, $D E R B Y$ a dummy equal to 1 if the match involved teams who are historical or local rivals and 0 otherwise, WEEKDAY a dummy equal to 1 if the game was televised on Monday to Friday inclusive (except Boxing Day) and 0 otherwise, BOXING DAY a dummy equal to 1 if the game was televised on Boxing Day (Thursday the $26^{\text {th }}$ of December 2013) and 0 otherwise (not included in Buraimo and Simmons, 2015), BT SPORT a dummy equal to 1 if the match was televised by the broadcaster BT Sport and 0 otherwise (Sky), OUTCOME UNCERTAINTY the absolute difference in home-win probability and away team probability derived from the bookmakers' odds and adjusted for over-round (bookmakers' margin), and the five variables related to INTENSITY the intensity of the game played during the second half of the season (January to May) regarding: 
- the first position for CHAMPIONSHIP INTENSITY;

- a position qualifying for the Champions League (second, third and fourth) without being in contention for the first position for CHAMPIONS LEAGUE INTENSITY;

- a position qualifying for the Europa League without being in contention for the first two prizes (fifth and potentially sixth and seventh) for EUROPA LEAGUE INTENSITY;

- a position that could qualify for the Europa League without being in contention for the first three prizes (sixth and seventh as long as we do not know if a team among / not among the first five will win or be finalist in the FA Cup and / or win the League Cup) for POTENTIAL EUROPA LEAGUE INTENSITY;

- and a position leading to relegation (eighteenth, nineteenth and twentieth) for RELEGATION INTENSITY.

It is worth noting that the first four prizes are mutually exclusive as suggested by Scelles et al. (2016)'s findings. OLS is applied, followed by wild bootstrap standard errors with 100,000 replications $^{1}$.

\section{Results}

Results are shown in Table 1. For competitive intensity, three different variables were tested: a first variable with a value allocated to a team equal to 4 for a possibility of change as a consequence of the next game, 2 for the second game, 1 for the third, 0 otherwise (Model 1) ${ }^{2}$; a second variable equal to 2 for the next game, 1 for the second, 0 otherwise (Model 2); a

1. Following Buraimo and Simmons (2015), the Heckman selection model was applied to ensure that OLS estimates are not biased by the broadcasters' choice of games to televise. No selection bias was found (tests available upon request). Contrary to Buraimo and Simmons (2015), team and month effects were not controlled for.

2. With a value equal to 3 instead of 4 for the next game, similar results were found. 
third variable equal to 1 for the next game, 0 otherwise (Model 3). In the three models, a significant positive impact was found for WAGE, POINTS and DERBY, no significant impact for BOXING DAY and OUTCOME UNCERTAINTY, and a significant negative impact for OTHER MATCHES, WEEKDAY and BT SPORT. Results are consistent with Buraimo and Simmons (2015) for WAGE, OUTCOME UNCERTAINTY, WEEKDAY and BT SPORT (BT SPORT replacing SETANTA) but not for POINTS, OTHER MATCHES and DERBY, not significant in Buraimo and Simmons (2015) (they did not test BOXING DAY). Regarding the intensity variables, CHAMPIONSHIP INTENSITY has a significant positive impact in all models and CHAMPIONS LEAGUE INTENSITY in Models 2 and 3 while EUROPA LEAGUE INTENSITY, POTENTIAL EUROPA LEAGUE INTENSITY and RELEGATION INTENSITY have no significant impact.

Table 1

\section{Conclusion}

The article shows that in the EPL star quality has a significant positive impact on television audience whereas uncertainty of outcome has no significant impact, consistent with Buraimo and Simmons (2015). However, a significant positive impact of championship and Champions League and no significant impact of Europa League, potential Europa League and relegation intensity are found with the new measures, whereas Buraimo and Simmons (2015) find no significant impact for all contention measures. This means that the EPL should focus not only on creating the right incentives for clubs to attract the best players as concluded by Buraimo and Simmons (2015) but also on ensuring that most of its clubs are in contention to win the championship or qualify for the Champions League as this would maximise television audience. In other words, an overall competitive balance should be sought. This would require sharing TV revenue more equally between the 20 EPL clubs. 
It is anticipated that the leading English clubs would be opposed to such an egalitarian TV revenue sharing, other than sharing with other clubs also able to generate high revenues. In this context, consideration of a European Super League, first evoked in 1998 (before the periods studied in Buraimo and Simmons (2015) and this article), may be pertinent. At that juncture the combined importance of star quality and competitive balance was unclear. Given Buraimo and Simmons (2015) and this article, a case could now certainly be made for a European Super League. However, this consideration based on TV audience in the EPL contradicts that of Scelles et al. (2016) based on stadium attendance in the French Ligue 1.

Sky is the main broadcaster for the EPL and the Spanish league in the UK and also broadcasts the German and Italian leagues respectively in Germany and Italy. Interestingly, however, it lost Champions League TV rights for the 2015-2018 period in the UK. As such this could provide Sky with both an ideal position and an incentive to move forward on the project of a European Super League at the end of the current TV rights deal with the EPL (2016-2019).

\section{Acknowledgements}

We are grateful to Babatunde Buraimo, Stephen Morrow and an anonymous referee for their very helpful comments. Errors are our own.

\section{References}

Allan, S. 2004. "Satellite Television and Football Attendance: The Not So Super Effect." Applied Economics Letters 11: 123-125. doi:10.1080/1350485042000200231.

Andreff, W., and N. Scelles. 2015. "Walter C. Neale Fifty Years After: Beyond Competitive Balance, the League Standing Effect Tested with French Football Data." Journal of Sports Economics 16: 819-834. doi:10.1177/1527002514556621.

Buraimo, B., and R. Simmons. 2015. "Uncertainty of Outcome or Star Quality? Television Audience Demand for English Premier League Football." International Journal of the Economics of Business 22: 449-469. doi:10.1080/13571516.2015.1010282. 
Cox, A. 2015. "Spectator Demand, Uncertainty of Results, and Public Interest: Evidence from the English Premier League.” Journal of Sports Economics OnlineFirst. doi:10.1177/1527002515619655.

Pawlowski, T., and C. Anders. 2012. "Stadium Attendance in German Professional Football: The (un)Importance of Uncertainty of Outcome Reconsidered." Applied Economics Letters 19: 1553-1556. doi:10.1080/13504851.2011.639725.

Rumsby, B. 2016. "Premier League Clubs to Share $£ 8.3$ billion TV windfall." The Telegraph 4 February. Retrieved August 24, 2016, from http://www.telegraph.co.uk/sport/football/12141415/Premier-League-clubs-to-share8.3-billion-TV-windfall.html

Scelles, N., C. Durand, L. Bonnal, D. Goyeau, and W. Andreff. 2013a. "Competitive Balance Versus Competitive Intensity Before a Match: Is One of these Two Concepts More Relevant in Explaining Attendance? The Case of the French Football Ligue 1 over the Period 2008-2011." Applied Economics 45: 4184-4192. doi:10.1080/00036846.2013.770124.

Scelles, N., C. Durand, L. Bonnal, D. Goyeau, and W. Andreff. 2013b. "My Team Is in Contention? Nice, I Go to the Stadium! Competitive Intensity in the French Football Ligue 1.” Economics Bulletin 33: 2365-2378.

Scelles, N., C. Durand, L. Bonnal, D. Goyeau, and W. Andreff. 2016. "Do All Sporting Prizes Have a Significant Positive Impact on Attendance in a European National Football League? Competitive Intensity in the French Ligue 1.” Ekonomicheskaya Politika /Economic Policy 11: 82-107. doi:10.18288/1994-5124-2016-3-06. In Russian, English version at https://mpra.ub.uni-muenchen.de/73844/

Wang, C., D. Goossens, and M. Vandebroek. 2016. "The Impact of the Soccer Schedule on TV Viewership and Stadium Attendance: Evidence from the Belgian Pro League." Journal of Sports Economics OnlineFirst. doi:10.1177/1527002515612875. 
Table 1. OLS models of $\ln$ (TV audience) followed by wild bootstrap standard errors.

\begin{tabular}{cccc}
\hline & Model 1 & Model 2 & Model 3 \\
\hline WAGE & $0.199(19.95)^{* * *}$ & $0.217(27.13)^{* * *}$ & $0.215(24.28)^{* * *}$ \\
POINTS & $0.101(9.43)^{* * *}$ & $0.087(8.60)^{* *}$ & $0.090(7.87)^{* *}$ \\
OTHER MATCHES & $-1.132(154.77)^{*}$ & $-1.019(219.14)^{* *}$ & $-0.985(281.55)^{*}$ \\
DERBY & $0.202(5.95)^{* *}$ & $0.168(5.47)^{* *}$ & $0.161(4.48)^{*}$ \\
WEEKDAY & $-0.156(5.21)^{* *}$ & $-0.184(9.38)^{* * *}$ & $-0.173(7.51)^{* *}$ \\
BOXING DAY & $0.607(50.90)$ & $0.630(83.66)$ & $0.613(67.23)$ \\
BT SPORT & $-0.818(191.85)^{* * *}$ & $-0.828(199.09)^{* * *}$ & $-0.808(195.42)^{* * *}$ \\
OUTCOME & $-0.037(0.12)$ & $-0.040(0.15)$ & $-0.063(0.36)$ \\
UNCERTAINTY & $0.046(14.00)^{* * *}$ & $0.087(10.59)^{* * *}$ & $0.167(7.73)^{* *}$ \\
CHAMPIONSHIP & $0.037(4.01)$ & $0.110(6.92)^{*}$ & $0.206(8.13)^{* * *}$ \\
INTENSITY & $0.130(2.92)$ & $0.101(0.84)$ & $0.148(0.72)$ \\
CHAMPIONS LEAGUE & & & $0.320(6.64)$ \\
INTENSITY & $0.116(4.25)$ & $0.096(9.30)$ & $-0.040(0.38)$ \\
EUROPA LEAGUE & $-0.006(0.19)$ & $-0.016(0.22)$ & $13.087(19148.53)^{* * *}$ \\
INTENSITY & 0.715 & $13.090(20824.94)^{* * *}$ & 0.712 \\
POTENTIAL EUROPA & & 0.711 & 154 \\
LEAGUE INTENSITY & $13.084(18503.37)^{* * *}$ & & \\
RELEGATION & & & \\
INTENSITY & R & & \\
Constant & & &
\end{tabular}

Notes: Numbers in parentheses are Quasi-F test statistics for wild bootstrap standard errors with 100,000 replications. Clustered by round of match using robust standard errors.

$* p<0.1, * * p<0.05, * * * p<0.01$. 